\title{
Infestation of mistletoe Dendrophthoe pentandra (L.)Miq on various canopy shading and plants diversity in Purwodadi Botanic Garden: A study on medicinal plant Cassia fistula $\mathbf{L}$.
}

\author{
Solikin \\ Purwodadi Botanic Garden, Research Center for Plant Conservation and Botanic Gardens - Indonesian Institute of Sciences \\ Jl. Raya Surabaya Malang km 65 Purwodadi Pasuruan East Java
}

\begin{abstract}
Mistletoe Dendrophthoe pentandra (L.)Miq is a parasitic plant commonly found parasitizing and infesting medicinal plants such as Cassia fistula L. This research aimed to investigate the infestation of $D$. pentandra on $C$. fistula on various trees canopy shading, infested host number and plant diversity. Study was conducted in Purwodadi Botanic Garden which located in Purwodadi, Pasuruan, East-Java during January-March 2020. Data Collection was conducted by explorative and descriptive methods in each block locations in the garden. Sampling plots were determined by purposive sampling method using $20 \times 20 \mathrm{~m}$ per plot in each block where the tree of $C$. fistula found. The canopy shading was categorized as : open (4) $=$ light interception $>90 \%$, rather open $(3)=$ light interception $=60-90 \%$, rather shady $(2)=$ light interception $30-60 \%$, shady $(1)($ light interception $<30 \%)$. The result showed that the infestation of D. pentandra was affected significanly by the plant canopy shading and the infested host number in the blocks. The highest infestation of misletoe D. pentandra on C. fistula was found in the open canopy and the highest infested host plants in the block III.D with the parasite number 13 per plant. The tree plant diversity in the blocks tend to have negative correlation to the infestation of $D$. pentandra on C. fistula with $\mathrm{r}=-0.18$.
\end{abstract}

Keywords: Dendrophthoe pentandra, Cassia fistula, infestation, mistletoe, medicinal plant.

Received: 14 August 2020 Revised: 07 September 2020 Accepted: 27 September 2020

\section{Introduction}

Mistletoe is shoot parasitic plant commonly found parasitizing and infesting wild and cultivated plants. Some species of the mistletoes have special characteristics for compatibility or specificity to their hosts which were determined by chemical, physiological and physical processes at the mistletoe-host interface ( de Buen \& Ornelas, 2002; Fadini, 2011). They live and only found on particular plant species as hosts such as Viscum articulatum on Dendrophthoe pentandra (Solikin, 2016) and Psittacanthus schiedeanus on Liquidambar styraciflua (de Buen \& Ornelas, 2002). The other mistletoes are generalist (Norton \& Carpenter, 1998; de Buen \& Ornelas, 2002) which parasitizing many plant species such as D. pentandra (360 species) (Xiao \& $\mathrm{Pu}$, 1988), Viscum album (452 species) (Barney et al., 1998); Dendrophthoe falcata (401 species) (Hawksworth et al., 1993); and Scurrula pulverulenta (81 species) (Pundir, 1995). Solikin (2016) reported that D.pentandra parasitized 86 plant species in Purwodadi Botanic Garden such as Cassia fistula, Sweitenia macrophylla, Mangifera indica, Citrus hystrix, Syzygium samarangensis and

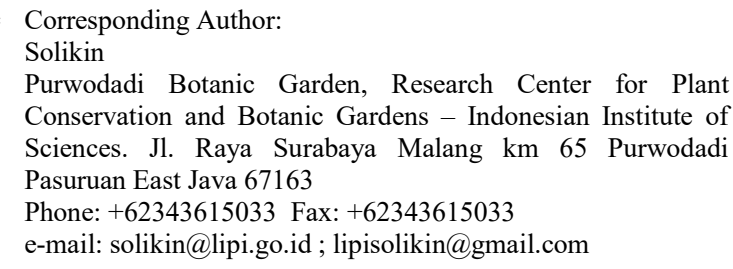

Annona squamosa. Although D. pentandra grow as a parasitic plant, it has has potential used for medicinal plants as antioxidant, antidiabetes (Artanti et al., 2012) and antibacterial (Hardiyanti et al., 2018).

Parasitization and infestation of mistletoes reduced growth, diminished vigor, premature mortality, impaired quality and quantity of wood, reduced fruit set, and heightened susceptibility to attack by other agents such as insects or fungi (Devkota, 2005), from mild to severe (Ward, 2005; Shen et al., 2010) which caused death of the hosts such as mistletoe Amyema preissii on Acacia victoriae (Reid et al., 1992). Barreda et al. (2012; 2013) reported that infestation of Viscum album had inhibited growing and caused mortality rates more than twice that of noninfested trees of scots pine (Pinus sylvestris L.).

Infestation and distribution the mistletoes on the host plants depend on biotic and abiotic factors such as infested host plants, dispersers, plants diversity, compatibility between host and parasite, and light interception in the plant canopy layers. Birds have important role on dispersal of the mistletoe seeds (Aukema \& del Río, 2002) such as the seeds of $D$. pentandra in Purwodadi Botanic Garden.

D. pentandra is hemiparasite (Solikin, 2016; 2020) which have green leaves for producing photoassimilates and obtaining water and nutrients from its hosts (Kuijt, 2009). Light is needed by this parasite for photosynthesis, seeds germination and plant growth. Thus, canopy shading by neighbour trees affect light interception on host canopy layer, seeds germination and growth of the 
parasite. De Buen \& Ornelas (2002) stated that light interception limited the postdispersal growth of the parasites, e.i. seed adhesion, seed germination, seedling establishment and seedling survival.

Cassia fistula is belongs to the family Leguminosae which was planted in several blocks in Purwodadi Botanic Garden as conserved plant which was reported as a dominant host for $D$. pentandra (Solikin, 2014a). Studies of $C$. fistula shown that this species has been evaluated as antimicrobial, antifungal, antipyretic, analgesic, larvicidal, antiinflammatory, antioxidant, antitumor, hepatoprotective, hypoglycemic activities, antidiabetic activity, and laxative property (Thirumal et al., 2012).

Investigation the infestation of $D$. pentandra on $C$. fistula on various neighbour trees canopy shading, host infested number and plant diversity is interesting because there is no information about this study, especially in Indonesian Botanic Gardens. It use and important to cultivate and control mistletoes for developing $C$. fistula as medicinal plant.

This research aimed to investigate the infestation of $D$. pentandra on $C$. fistula in various trees canopy shading and infested host number in Purwodadi Botanic Garden.

\section{Methods}

\section{Time and location}

Research was conducted in Purwodadi Botanic Garden (Fig. 1) during January - March 2020. The garden is located in Purwodadi District, Pasuruan Regency, East Java Province, Indonesia at about $300 \mathrm{~m}$ asl with area 85 hectares. Climate data from climate station in Purwodadi Botanic Garden during 2014 - 2019 was recorded average of precipitation, rainy day, air relative humidity $(\mathrm{RH})$, minimum and maximum temperature, i.e. $2232 \mathrm{~mm}$ per year, 152 days per year, $74.33 \%, 20.37{ }^{\circ} \mathrm{C}$ and $30.82^{\circ} \mathrm{C}$, respectively (Tab. 1).

\section{Data Collection and analysis}

Data Collection was conducted by explorative and descriptive methods in any block locations in the garden. Sampling plots were determined by purposive sampling method using $20 \times 20 \mathrm{~m}$ in each block where the tree of $C$. fistula found. There were 16 blocks determined and 18 plots made where $C$. fistula found (III.C, III.D, III.E, V.D, VI.B, IX.B, IX.C, XI.I, XII.F, XIII.D, XV.A, XX.F, XX.G, XIV.C, XXII.D, XXII.E). Tree species in each plot and block were invented, identified and counted their species and specimen number.

Vegetation analysis is conducted to determine tree plant species composition and indice of important value (IVI) plant domination (C), Shannon diversity (H'), evenness (E'). D. pentandra in plots and host parasited plants in the blocks was counted to know their relation to the parasite infestation and prevalence. Infested host prevalence by parasite show the proportion between the infested host and the total host number. The neighbour tree canopy cover or shading around and the top canopy of $C$. fistula in each plot location were categorized qualitatively as : open (4) = light interception $>90 \%$, rather open $(3)=$ light interception $=60-90 \%$, rather shady $(2)=$ light interception $30-60 \%$, shady (1) (light interception $<30 \%$ ). Infested host by $D$. pentandra in the blocks was categorized as : $0=$ not found; $1=$ too little $(1$ 2 host $) ; 2=$ little $(3-4$ host $) ; 3=\operatorname{lot}(5-6$ host $) ; 4=$ too lot ( $>6$ host). Shannon diversity, domination and evennnes Indice were counted according to Maqurran (2004). IVI was counted according to Krebs (1994). Data was analysed by Microsoft excel and nonparametrical statistic using MINITAB 13 program. Kruskal-Wallis test was used to determine differences between tree canopy shading, host infested plants and the parasite number. Pearson correlation test ( $r$ ) was used to know correlation between Shannon diversity and parasite number; tree species number and parasite number; trees specimen number and parasite number.

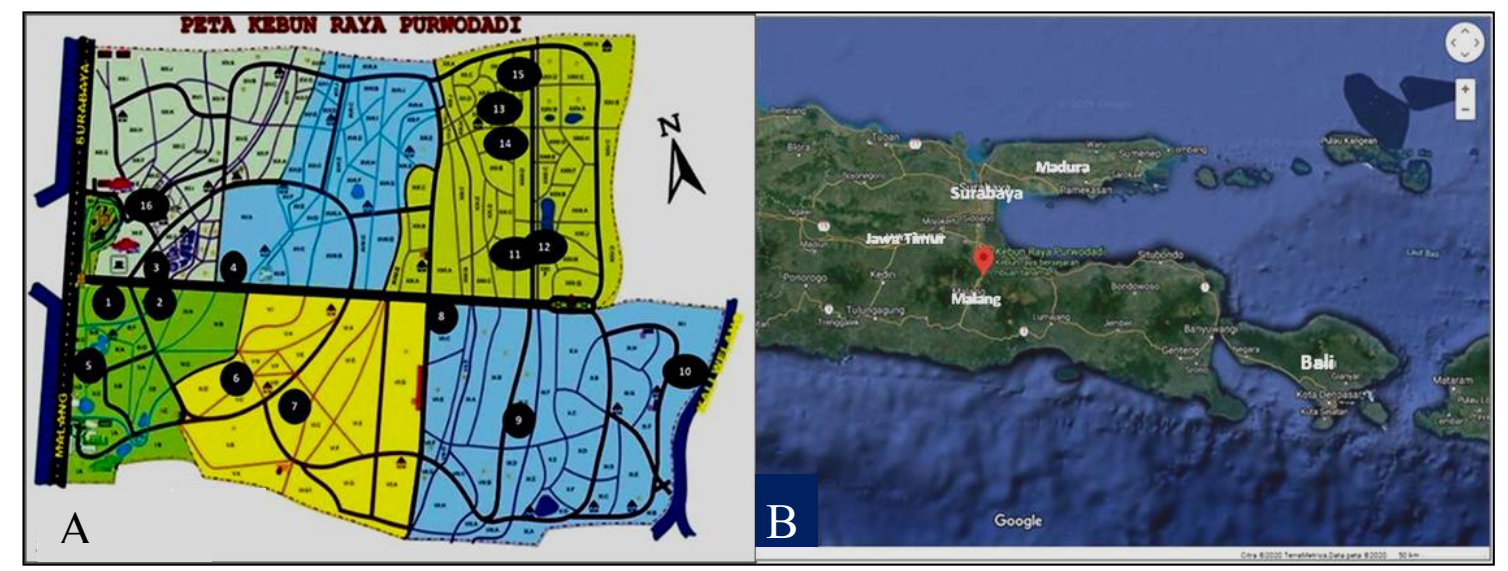

Figure 1. Reseach location: A. Map of Purwodadi Botanic Garden (Purwodadi Botanic Garden, 2013),

$\mathbf{x}=$ sampling plots; $\mathrm{B}$. Location of Purwodadi Botanic Garden 
Table 1. Climate data in Climate Station of Purwodadi Botanic Garden during 2014 - 2019

\begin{tabular}{cccccc}
\hline Year & $\begin{array}{c}\text { Precipitation } \\
\text { (mm/year) }\end{array}$ & $\begin{array}{c}\text { Rainy day } \\
\text { (days/year) }\end{array}$ & $\begin{array}{c}\text { Relative humidity } \\
(\mathbf{\%})\end{array}$ & $\begin{array}{c}\text { Temperature }\left({ }^{\circ} \mathbf{C}\right) \\
\text { Minimum }\end{array}$ \\
\hline 2014 & 1.676 & 157 & 72.66 & 20.30 & 30.68 \\
2015 & 1.568 & 141 & 74.64 & 20.27 & 30.28 \\
2016 & 3.134 & 162 & 74.45 & 20.45 & 31.32 \\
2017 & 3.554 & 193 & 72.45 & 20.62 & 31.66 \\
2018 & 1.939 & 143 & 75.07 & 20.70 & 30.70 \\
2019 & 1.564 & 115 & 76.71 & 2.037 \\
\hline
\end{tabular}

\section{Results}

\section{Tree plant diversity and composition}

The results showed that there were 63 species, 55 genera and 20 family of tree plant species found around $C$. fistula in all plots in the garden (Tab. 2). There were six species dominating around $C$. fistula such as Swietenia macrophylla King., Jacaranda obtusifolia Bonpl, Albizia saman (Jacq.) Merr. and Terminalia microcarpa Decne with IVI $29.45,26.48,19.87$, and 15.49 , respectively (Tab. 2).

Table 2. Relative density (RD), relative frequency (RF), relative domination (RDom) and important value index (IVI) of the plant species around Cassia fistula L. in Purwodadi Botanic Garden

\begin{tabular}{|c|c|c|c|c|c|c|}
\hline No. & Species & Family & RD & RF & RDom & IVI \\
\hline 1 & Cassia fistula $\mathrm{L}$. & Leguminosae & 18.11 & 20.00 & 13.47 & 51.58 \\
\hline 2 & Swietenia macrophylla King. & Meliaceae & 8.64 & 6.67 & 14.15 & 29.45 \\
\hline 3 & Jacaranda obtusifolia Bonpl. & Bignoniaceae & 19.75 & 5.83 & 0.90 & 26.48 \\
\hline 4 & Albizia saman (Jacq.) Merr. & Leguminosae & 3.29 & 3.33 & 13.25 & 19.87 \\
\hline 5 & Terminalia microcarpa Decne & Combretaceae & 2.06 & 2.50 & 10.93 & 15.49 \\
\hline 6 & Ceiba pentandra (L.) Gaertn. & Malvaceae & 2.47 & 2.50 & 5.08 & 10.05 \\
\hline 7 & Diospyros malabarica (Desr.)Kostel. & Ebenaceae & 4.53 & 3.33 & 2.17 & 10.03 \\
\hline 8 & Enterolobium cyclocarpum (Jacq.)Griseb & Leguminosae & 1.23 & 1.67 & 6.75 & 9.65 \\
\hline 9 & Pterocarpus indicus Willd. & Leguminosae & 2.06 & 2.50 & 3.97 & 8.53 \\
\hline 10 & Wrightia arborea (Dennst.) Mabb & Apocynaceae & 2.47 & 1.67 & 0.73 & 4.87 \\
\hline 11 & Madhuca longifolia (J. Konig ex L.) J.F. Macbr. & Sapotaceae & 1.23 & 1.67 & 1.80 & 4.70 \\
\hline 12 & Lagerstromea loudonii Teijm\&Binn. & Lytheraceae & 0.82 & 1.67 & 1.74 & 4.23 \\
\hline 13 & Lagerstroemia duperiana Pierre ex Gagnep & Lytheraceae & 0.82 & 1.67 & 1.72 & 4.21 \\
\hline 14 & Mangifera indica $\mathrm{L}$. & Anacardiaceae & 1.23 & 1.67 & 0.50 & 3.40 \\
\hline 15 & Metroxylon sagu Rotb. & Arecaceae & 2.06 & 0.83 & 0.49 & 3.38 \\
\hline 16 & Syzygium sexangulatum (Miq.)Amsh. & Myrtaceae & 0.82 & 1.67 & 0.72 & 3.21 \\
\hline 17 & Livistona rotundifolia (Lam.) Mart. & Arecaceae & 1.23 & 1.67 & 0.12 & 3.02 \\
\hline 18 & Gliricidea sepium (Jacq.)Walp. & Leguminosae & 0.82 & 1.67 & 0.47 & 2.96 \\
\hline 19 & Diospyros celebica Bakh. & Ebenaceae & 1.23 & 0.83 & 0.71 & 2.78 \\
\hline 20 & Kigelia africana (Lam.) Benth. & Bignoniaceae & 0.41 & 0.83 & 1.52 & 2.76 \\
\hline 21 & Eucalyptus globulus Labill. & Myrtaceae & 0.82 & 0.83 & 1.09 & 2.75 \\
\hline 22 & Parkia timoriana (DC) Merr. & Leguminosae & 0.41 & 0.83 & 1.44 & 2.68 \\
\hline 23 & Miliusa horsfieldii (Bennett) Baill. ex Pierre & Annonaceae & 1.65 & 0.83 & 0.14 & 2.62 \\
\hline 24 & Streblus asper Lour. & Moraceae & 1.65 & 0.83 & 0.12 & 2.60 \\
\hline 25 & Peltophorum pterocarpum (DC) K.Heyne & Leguminosae & 0.41 & 0.83 & 1.24 & 2.48 \\
\hline 27 & Caryota rumphiana Mart. & Arecaceae & 0.82 & 0.83 & 0.73 & 2.39 \\
\hline 28 & Acacia oraria F.Muell. & Leguminosae & 1.23 & 0.83 & 0.28 & 2.35 \\
\hline 29 & Ficus callosa Willd. & Moraceae & 0.41 & 0.83 & 1.05 & 2.30 \\
\hline 30 & Aleurites moluccana (L.) Willd. & Euphorbiaceae & 0.41 & 0.83 & 1.02 & 2.26 \\
\hline 31 & Voacanga sp. & Apocynaceae & 0.82 & 0.83 & 0.51 & 2.17 \\
\hline 32 & Tectona grandis L.f. & Verbenaceae & 0.41 & 0.83 & 0.92 & 2.16 \\
\hline 33 & Adonidia merrillii (Becc.) Becc. & Arecaceae & 1.23 & 0.83 & 0.08 & 2.15 \\
\hline 34 & Firmiana malayana Kosterm. & Sterculiaceae & 0.82 & 0.83 & 0.46 & 2.12 \\
\hline 35 & Spathodea campanulata L. Beauv. & Bignoniaceae & 0.41 & 0.83 & 0.79 & 2.04 \\
\hline 36 & Albizia chinensis (Osbeck) Merr. & Leguminosae & 0.41 & 0.83 & 0.76 & 2.01 \\
\hline 37 & Eucalyptus alba Reinw. Ex Blume & Myrtaceae & 0.41 & 0.83 & 0.76 & 2.01 \\
\hline
\end{tabular}




\begin{tabular}{|c|c|c|c|c|c|c|}
\hline 38 & Delonix regia (Hook.) Raf. & Leguminosae & 0.41 & 0.83 & 0.73 & 1.98 \\
\hline 39 & Bombax ceiba $\mathrm{L}$. & Malvaceae & 0.82 & 0.83 & 0.28 & 1.94 \\
\hline 40 & Cinnamomum verum J. Presl. & Lauraceae & 0.41 & 0.83 & 0.59 & 1.84 \\
\hline 41 & Cinnamomum camphora (L.) J.Presl. & Lauraceae & 0.41 & 0.83 & 0.52 & 1.76 \\
\hline 42 & Albizia procera (roxb.) Benth. & Leguminosae & 0.41 & 0.83 & 0.49 & 1.74 \\
\hline 43 & Areca macrocalyx Zipp ex Blume & Arecaceae & 0.82 & 0.83 & 0.06 & 1.71 \\
\hline 44 & Alstonia scholaris (1.)R.Br. & Apocynaceae & 0.41 & 0.83 & 0.47 & 1.71 \\
\hline 45 & Erytrina variegata $\mathrm{L}$. & Leguminosae & 0.41 & 0.83 & 0.47 & 1.71 \\
\hline 46 & Vitex pinnata $\mathrm{L}$. & Verbenaceae & 0.41 & 0.83 & 0.47 & 1.71 \\
\hline 47 & Elaeis guinensis Jacq. & Arecaceae & 0.41 & 0.83 & 0.42 & 1.67 \\
\hline 48 & Plumeria alba $\mathrm{L}$. & Apocynaceae & 0.41 & 0.83 & 0.28 & 1.53 \\
\hline 49 & Kopsia arborea Blume & Apocynaceae & 0.41 & 0.83 & 0.20 & 1.44 \\
\hline 50 & Pimenta dioica (L.) Merr. & Myrtaceae & 0.41 & 0.83 & 0.20 & 1.44 \\
\hline 51 & Anadenathera peregrina (L.) Speg & Leguminosae & 0.41 & 0.83 & 0.18 & 1.43 \\
\hline 52 & Anthochepalus sp & Rubiaceae & 0.41 & 0.83 & 0.18 & 1.43 \\
\hline 53 & Dehaasia $\mathrm{sp}$ & Lauraceae & 0.41 & 0.83 & 0.18 & 1.43 \\
\hline 54 & Plumeria rubra L. & Apocynaceae & 0.41 & 0.83 & 0.18 & 1.43 \\
\hline 55 & Syzygium acuminatissimum (Blume) DC & Myrtaceae & 0.41 & 0.83 & 0.18 & 1.43 \\
\hline 56 & Actinoritis callapparhia (Blume) H. Wendl \& Drune ex & Arecaceae & 0.41 & 0.83 & 0.13 & 1.37 \\
\hline 57 & Lannea coromandelica (Houst.) Merr. & Anacardiaceae & 0.41 & 0.83 & 0.13 & 1.37 \\
\hline 58 & Morinda citrifolia $\mathrm{L}$. & Rubiaceae & 0.41 & 0.83 & 0.13 & 1.37 \\
\hline 59 & Maniltoa rosea (K. Schum)Meeuwen & Leguminosae & 0.41 & 0.83 & 0.06 & 1.30 \\
\hline 60 & Syzygium nervosum A.Cunn. Ex DC. & Myrtaceae & 0.41 & 0.83 & 0.05 & 1.29 \\
\hline 61 & Cassia leptophylla Vogel & Leguminosae & 0.41 & 0.83 & 0.03 & 1.27 \\
\hline 62 & Dysoxylum sp & Meliaceae & 0.41 & 0.83 & 0.02 & 1.26 \\
\hline 63 & Mischocarpus sp. & Sapindaceae & 0.41 & 0.83 & 0.02 & 1.26 \\
\hline
\end{tabular}

Table 3. Kruskall Wallis test and Pearson correlation of some variables of canopy shading

\begin{tabular}{lcc}
\hline Relationship of variables & Kruskall Wallis & Pearson Correlation \\
\hline Infested host x parasite infesting & $\mathrm{P}=0.018$ & - \\
Canopy Shading x parasite infesting & $\mathrm{P}=0.030$ & - \\
Shannon diversity Index x parasite number & - & $\mathrm{r}=-0.17 ; \mathrm{P}=0.53$ \\
Domination index x parasite number & - & $\mathrm{r}=0.26 ; \mathrm{P}=0.34$ \\
Evennes index x parasite number & - & $\mathrm{r}=-0.37 ; \mathrm{P}=0.17$ \\
Species number in plot x parasite number & - & $\mathrm{r}=-0.08 ; \mathrm{P}=0.77$ \\
Species number in plot (site) x parasite number & - & $\mathrm{r}=-0.19 ; \mathrm{P}=0.49$ \\
Specimen number in plot x parasite number & - & $\mathrm{r}=-0.39 ; \mathrm{P}=0.14$ \\
Infested hosts x parasite number & $\mathrm{r}=0.82 ; \mathrm{P}=0.00$ \\
\hline
\end{tabular}

Table 4. Domination index C), evennes index (E'). diversity index (H'), host prevalence, host species, host specimen and parasite number in each Block. Note : *) Cassia fistula L.

\begin{tabular}{|c|c|c|c|c|c|c|c|c|c|c|c|c|c|}
\hline \multirow{2}{*}{ No. } & \multirow{2}{*}{ Block } & \multirow{2}{*}{$\begin{array}{l}\text { Canopy } \\
\text { shading }\end{array}$} & \multirow{2}{*}{$\begin{array}{c}\text { Plot } \\
\text { number }\end{array}$} & \multirow{2}{*}{ C } & \multirow{2}{*}{$\mathrm{E}^{\prime}$} & \multirow{2}{*}{$\mathrm{H}^{\prime}$} & \multirow{2}{*}{$\begin{array}{l}\text { Host } \\
\text { in } \\
\text { block }\end{array}$} & \multirow{2}{*}{$\begin{array}{c}\text { Host } \\
\text { prevale-nce } \\
* \text { *) }\end{array}$} & \multirow{2}{*}{$\begin{array}{l}\text { Parasite } \\
\text { number }\end{array}$} & \multicolumn{2}{|c|}{ Species number } & \multicolumn{2}{|c|}{ Specimen number } \\
\hline & & & & & & & & & & Plot & Block & Plot & Block \\
\hline 1 & XXII.D & 2 & 1 & 0.14 & 0.98 & 2.04 & 0 & 0.00 & 0 & 8 & 67 & 8 & 143 \\
\hline 2 & XXII.E & 2 & 1 & 0.24 & 0.94 & 1.50 & 1 & 0.00 & 0 & 5 & 29 & 10 & 56 \\
\hline 3 & XX.G & 2 & 1 & 0.16 & 0.94 & 1.95 & 0 & 0.00 & 0 & 8 & 63 & 13 & 114 \\
\hline 4 & XX.F & 2 & 2 & 0.22 & 0.97 & 1.55 & 0 & 0.00 & 0 & 5 & 56 & 22 & 76 \\
\hline 5 & XIII.D & 2 & 1 & 0.25 & 1.00 & 1.38 & 1 & 0.00 & 0 & 4 & 36 & 4 & 42 \\
\hline 6 & IX.B & 3 & 1 & 0.20 & 1.00 & 1.61 & 2 & 2.27 & 9 & 4 & 14 & 5 & 18 \\
\hline 7 & IX.C & 3 & 1 & 0.28 & 0.96 & 1.32 & 2 & 0.00 & 0 & 4 & 53 & 6 & 67 \\
\hline 8 & XI.I & 3 & 2 & 0.32 & 0.95 & 2.17 & 0 & 0.00 & 0 & 10 & 36 & 12 & 50 \\
\hline 9 & III.C & 3 & 1 & 0.10 & 0.94 & 2.41 & 2 & 2.27 & 6 & 13 & 15 & 18 & 15 \\
\hline 10 & XXIV. & 1 & 1 & 0.32 & 0.84 & 1.35 & 0 & 0.00 & 0 & 5 & 5 & 16 & 50 \\
\hline 11 & VI.B & 1 & 1 & 0.16 & 0.97 & 1.88 & 1 & 0.00 & 0 & 7 & 11 & 9 & 35 \\
\hline 12 & III.D & 4 & 2 & 0.37 & 0.81 & 1.12 & 4 & 27.27 & 13 & 4 & 57 & 23 & 75 \\
\hline 13 & III.E & 4 & 2 & 0.45 & 0.85 & 1.65 & 4 & 20.45 & 7 & 7 & 5 & 12 & 35 \\
\hline 14 & XII.F & 4 & 2 & 0.52 & 0.63 & 0.88 & 3 & 13.64 & 5 & 4 & 6 & 10 & 22 \\
\hline 15 & XV.A & 4 & 1 & 0.28 & 0.96 & 1.33 & 3 & 2.27 & 4 & 4 & 20 & 6 & 50 \\
\hline 16 & V.D & 4 & 2 & 0.23 & 0.85 & 1.77 & 2 & 0.00 & 0 & 8 & 67 & 23 & 55 \\
\hline
\end{tabular}




\section{Infestation and prevalence of $D$. pentandra on various canopy shading}

There is significant affect between the trees canopy shading and parasite infestation on C. fistula $(\mathrm{P}<0.05)$ (Tab. 3). The most infestation of the parasite on $C$. fistula was found in open location III.D (Fig. 2) with parasite population 13 parasites per plant. Infested host number in the blocks affect significanly on parasite number infesting on $C$. fistula $(\mathrm{P}<0.05)$ (Tab. 3). The highest infested host number by $D$. pentandra was in block III.D with infested host prevalence $27.27 \%$ (Tab. 4).

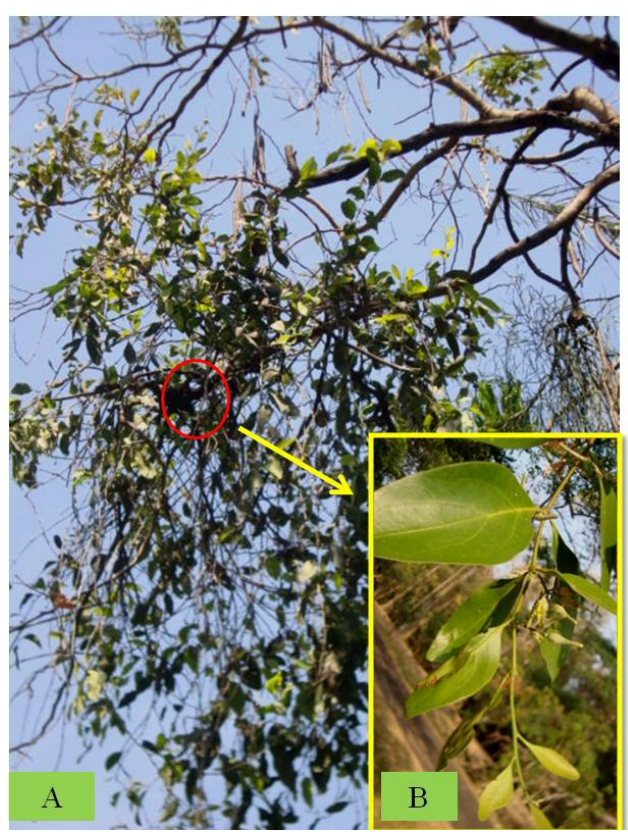

Figure 2. A. D. pentandra on Cassia fistula in block III.D; B. D. pentandra

\section{Discussion}

Plant diversity in plots in the blocks is categorized to be low $\left(\mathrm{H}^{\prime}<1\right)$, moderate $\left(1<\mathrm{H}^{\prime}<2\right)$ and high $\left(\mathrm{H}^{\prime}>2\right)$ (Kent \& Paddy 1992). These variation is caused by the difference of species and specimen number in the plots. The lowest value of H' (0.88) in the block XII.F is caused by the lowest species and specimen number in the plot (Tab. 4). In contrast, the highest H' (2.41) in III.C is caused the highest species and specimen number in the plot (Tab. 4). Plant diversity in all plots in the blocks around $C$. fistula is high $\left(\mathrm{H}^{\prime}>2\right)$. It is caused by many tree species and specimens number, i.e. 63 species and 203 specimens, respectively. Actually, plant diversity in the garden is very high. It is related to the function of the garden for plants conservation, especially plants from dry lowland area in Indonesia. Purwodadi Botanic Garden has collected living plant 2157 species, 997 genera and 179 families in the garden until 2020. It is not included plants for reforestation, road side avenue, forested area and wild plants.

Swietenia macrophylla is the most dominant species around C. fistula with IVI 29.45 (Tab. 2). This species is to be dominant in the garden which planted for reforestation, road side avenue and arboretum. It is also found growing wild in the garden. Reforestation with $S$. macrophylla was conducted for soil and water conservation for many years ago and also to be used as shading and climbing place for particular plants collection such as rattans. Pterocarpus indicus and Albizia saman were also planted for the same as function on $S$. macrophylla in the garden. The distribution of $S$. macrophylla in the garden have potential to be broad because it has samara seed type which has potential to disperse by wind far from the main plant. So their seedling can be almost found in almost areas in the garden.

The plants domination index in all plots in the blocks are relatively low $(\mathrm{C}<0.5)$ except in XII.F was moderate $(0.75>\mathrm{C}>0.5)(\mathrm{Krebs}, 1994)$. It is indicate that there is no domination particular plant species around C. fistula. It is also shown by evenness index (E') in all plots $>0.75$, except in XII.F. $=0.63$. The $E^{\prime}>0.75$ shows that the ecosystem in the plots is stable. In contrast, $0.5<\mathrm{E}^{\prime}<$ 0.75 such as in XII.F is moderate which shows the ecosystem less stable.

Plant diversity, domination, and evennesss in all blocks has not significant correlation $(\mathrm{P}>0.05)$ to parasite number of $D$. pentandra in given areas with $\mathrm{r}=$ -0.17 and $\mathrm{P}=0.53 ; \mathrm{r}=0.26$ and $\mathrm{P}=0.34 ; \mathrm{r}=-0.37$ and $\mathrm{P}=0.17$, respectively (Tab. 3 ). The correlation between species number and specimen number in all plot site locations and parasite number also not significant with $\mathrm{r}$ $=-0.079 ; \mathrm{P}=0,771$ and $\mathrm{r}=-0.385 ; \mathrm{P}=0.141$, respectively. However, there is a tendency of negative correlation between plant diversity, plant species and specimen number with parasite number infestation on $C$. fistula, i.e. $\mathrm{r}=-0.169, \mathrm{r}=-0,079$, and $\mathrm{r}=-0.385$ respectively (Tab. 3). Tree plant diversity correlates to diversity of stucture and canopy of plant species in a community. It affects light interception and infestation of mistletoe $D$. pentandra which need much light for its seeds germination and growth. Swietenia macrophylla, Albizia saman, Terminalia microcarpa and Pterocarpus indicus which were found in shady plots such as XX.D (143 species) and XX.G (114 species) have higher structure and larger canopies than those on C. fistula. They will shade and reduce light interception on the canopy of $C$. fistula so there is not D. pentandra on $C$. fistula in plots XXD and XX.G foud. Luo et al. (2016) also reported that the infestation parasite $(D$. pentandra) in a community with higher plant species richness(16.5) and diversity index (2.27) is lower (1.8) than those in community with low richness (3.5) and diversity index (0.8).

The occurrence of infested hosts whether on $C$. fistula or other plant species is important for distribution and infestation of $D$. pentandra. There is positive and significant correlation $(\mathrm{P}<0.05)$ between the number of infested hosts and the parasite number on $C$. fistula with $\mathrm{r}=0.817$ and P-Value $=0.000$ (Tab. 3). It indicates that infested host number have important role on the distribution and infestation of the mistletoe $D$. pentandra on C. fistula. Luo et al. (2016) also reported significant relationship between the abundance of infested indvidual hosts and mistletoes infection in plantation.

Birds distribute seeds of the parasite in given infested plant or to other uninfested plants after perching, 
excreting and depositing the seeds on the branches and twigs. There were specialist and generalist birds which have important role on the seeds mistletoe dispersal such as $D$. pentandra . The birds from genera Dicaeum such as Dicaeum concolor "flower pecker" is categorized as specialist mistletoes, whereas yellow-vented bulbul (Pycnonotus xanthopygos) as generalist frugivorous (Luo et al. 2016). Yellow-vented bulbul " trucukan" ( $P$. goavier) and "kutilang" ( $P$. aurigaster) as frugivorous birds were also found in the garden as fruits eater such as the fuits of mistletoes. They will disperse and distribute the seeds of mistletoes to new host plants which far from the main host because they able to move and fly more far than the specialist birds. The specialist birds (flower peckers) are nomadic birds and they move and fly no far, efectively 1-10 m (Aukema \& del Río, 2002) so they will be intensiving the seeds dispersal on infested plants or other hosts near them. Davidar (1983) reported that Dicaeum concolor as specialist bird has territorial around clumps of fruiting mistletoes, restricting their feeding to these areas and will agregate mistletoes distribution on the host plants by seeds depositing on the hosts. Consequently, this species may have a short dispersal range and may contribute to the smaller scale of agregation in the plantation. In contrast, the dietary generalist yellow-vented bulbul' trucukan" ( $P$. goavier $)$ "kutilang" ( $P$. aurigaster $)$ as reported on $P$. jocosus (Linnebjerg, Hansen, \&Olesen, 2009) is more likely to visit uninfected trees for social interactions and selfmaintenance activities such as preening. They tend to spend more time foraging on mistletoe fruits and usually fly long distances.

Canopy shading by neighbor plants relate to light capturing by plants canopy and mistletoes life on branches and twigs. Canopy shading will affect growth, infestation and distribution of mistletoes (Norton \& Ladley, 1998; Aukema \& del Río, 2002; Roxburgh \& Nicolson, 2005), especially for survival of hemiparasite ( de Buen \& Ornelas, 2002). D. pentandra need much light for its growth and development so this parasite is commonly found in the top or outer plants canopy where much light intercepted. Light is needed by hemiparasites for photosyntesis to produce carbohydrate to support plant growth and development.

Light incidence on the plant canopies limited the post-dispersal growth of the parasites, e.i. seed adhesion, seed germination, seedling establishment and seedling survival of the mistletoes (de Buen \& Ornelas, 2002). The seeds germination, seedlings growth and survival of $D$. pentandra to be better on trees with open canopies than shady canopy. Solikin (2014b) also reported that seed germination of $D$. pentandra need much light for better germination and plant growth. It is also showed that the parasite grow well in the garden and found more on the branches or twigs intercepting much sunlight (Solikin, 2014b, 2016). Norton \& Ladley, (1998) also reported that establishment of the parasite Alepis flavida in Nothofagus salandri forests of New Zealand was better on branches experiencing higher light levels. Table 4 showed that the infestation of D. pentandra on C. fistula in the open canopy such as in III.D higher than that in shady canopy (XX.F). There is significant different between canopy shading and the parasite number infesting on $C$. fistula with $\mathrm{P}=0$. 018. The highest number of parasites was found in open canopy.

This research can be concluded that the infestation of D. pentandra (L.) Miq affected significanly by the plant canopy shading and the infested host number. The highest infestation of misletoe Dendrophthoe pentandra. on host Cassia fistula L. in Purwodadi Botanic Garden was in the open canopy and the highest infested host plants in the block III.D with the parasite number 13 per plant. The tree plant diversity in the blocks tend to have negative correlation to the infestation of $D$. pentandra on C. fistula with $\mathrm{r}=-0.18$.

\section{Acknowledgement}

I would like to thank to Mr. Andarta F. Khoir who give the climate data Purwodadi Botanic Garden during 2014-2019.

\section{References}

Artanti, N., Firmansyah, T., \& Darmawan A. (2012). Bioactivities Evaluation of Indonesian Mistletoes (Dendrophthoe pentandra (L.) Miq.) Leaves Extracts. Journal of Applied Pharmaceutical Science, 2 (1), 24-27.

Aukema, J. E., \& del Río, M. C. (2002). Where does a fruit-Eating bird deposit mistletoe seeds? Seed deposition patterns and an experiment. Ecology, 83, 489-496.

Barney, C. W., Hawksworth, F. G., \&Geils, B. W. (1998). Hosts of Viscum album. European Journal of Forest Pathology, 28, 187-208

Barreda, S. G. J., Linares, C., \& Camarero, J. J. (2012). Mistletoe effects on Scots pine decline following drought events: insights from within-tree spatial patterns, growth and carbohydrates. Tree Phsiology, 32, 585-598.

Barreda, S. G. J., Linares, C., \& Camarero, J. J. (2013). Drought and mistletoe reduce growth and water-use efficiency of Scots pine. Forest Ecology and Management, 296, 64-73.

Davidar, P. (1983). Birds and neotropical mistletoes: effects on seedling recruitment. Oecologia, 60, 271-273.

de Buen, L. L., \& Ornelas, J. F. (2002). Host compatibility of the cloud forest mistletoe Psittacanthus schiedeanus (Loranthaceae) in Central Veracruz, Mexico. American Journal of Botany, 89, 95-102.

Devkota, M. P. (2005). Biology of mistletoes and their status in Nepal Himalaya. Himalayan Journal of Sciences, 3(5), 8588.

Fadini, R. F. (2011). Non-overlap of hosts used by three congeneric and sympatric loranthaceous mistletoe species in an Amazonian savanna: host generalization to extreme specialization. Acta Botanica Brasilica, 25, 337-345.

Hardiyanti, R., Marpaung, L., Adyana, I. K.., \& Simanjuntak, P. (2018). Antioxidan and antibcterial activity of various extract of 'duku's mistletoe (Dendrophtoe pentandra (L.) Miq.) leaves extracs. Asian Journal of Pharmaceutical and Clinical Research, 11(12), 526-529.

Hawksworth, F. G., Pundir, Y. P. S, Shaw, C. G., \& Geils, B. W. (1993). The host range of Dendroepthoe falcata (L. f.) Etttings (Loranthaceae). Indian Journal of Forestry, 16(3), 263-281.

Kent, M., \& Paddy, C. (1992). Vegetation Description and Analysis a Practical Approach. London. Belhaven Press.

Krebs, C. J. (1994). Ecology (4th ed.). New York Harper Colleus Publishers.

Kuijt, J. (2009). Monograph of Psittacanthus (Loranthaceae). Systematic Botany Monographs, 86, 1-361.

Linnebjerg, J. F., Hansen, D. M., \& Olesen, J. M.(2009). Gut passage effect of the introduced red-whiskered bulbul (Pycnonotus jocosus) on germination of invasive plant species in Mauritius. Austral Ecology, 34, 272-277. 
Luo, Y., Sui, Y., Gan, J., \& Zhang, L. (2016). Host compatibility interacts with seed dispersal to determine small-scale distribution of a mistletoe in Xishuangbanna, southwest China. Journal of Plant Ecology, 9(1), 77-86.

Magurran, A. (2004). Measuring Biological Diversity. Oxford. Blackwell Publishing.

Norton, D. A., \& Carpenter, M.A. (1998). Mistletoes as parasites: host specifcity and speciation. Trends in Ecology \& Evolution, 13, 101-105.

Pundir, Y. P. S. (1995). Host range of Scurrula pulverulenta (Wall.) G. Don.Loranthaceae from Dun valley and adjacent areas. Indian Journal of Forestry, 18, 74-79.

Purwodadi Botanic Garden. (2013). An Alphatical List of Plant Species Cultivated in The Botanic Garden. Pasuruan, East Java : D. Narko, A. Suprapto, \& W.Lestarini (eds).

Reid, N., Smith, D. M. S.,Venables, W. N. (1992). Effect of mistletoes (Amyema preissii) on host (Acacia victoriae) survival. Australian Journal of Ecology, 17(2), 219-222. doi:10.1111/j.1442-9993. 1992.tb00800.x

Roxburgh, L., \& Nicolson, S. W. (2005). Patterns of host use in two African mistletoes: the importance of mistletoe-host compatibility and avian disperser behaviour. Functional Ecology, 19, 865-873.

Shen, H., Prider, J. N., Facelli, J. M., \& Watling, J. R. (2010). The influence of the hemiparasitic angiosperm Cassytha pubescens on photosynthesis of its host Cytisus scoparius. Functional Plant Biology, 37(1), 14-21. doi:10.1071/FP09135
Solikin. (2014a). Parasitic plants on medicinal plants: Study in Purwodadi Botanic Garden. In M. Rizal, Januawati, Y. Widyastuti, L. Brotokardono, R. Effendi, D. Rohadi, \& T. Herwati (Eds.), International Seminar Proceedings Forest \& Medicinal Plants for Better Human Welfare (pp. 35- 46), Bogor. Indonesia: Centre for Forest Productivity Research and Development. .

Solikin. (2014b). Upaya Perbanyakan Generatif Benalu Dendrophtoe pentandra (L.) Miq. Prosiding Simposium Penelitian Bahan Obat Alami (SPBOA) \& Muktamar XII PERHIPBA pp. 171177), Yogyakarta. Indonesia.

Solikin. (2016). Population Dyniamic of Viscum articulatum Burm.f. on Its Host in Purwodadi Botanic Garden. Journal of Biological Recsearches, 21(2), 81-84.

Solikin. (2020). Parasitization of Parasitic Plants on Fruit Plants in Bangkalan Regency and Malang City, Indonesia. Ecology. Environment. \& Conservation, 26, 27-35.

Thirumal, V. M., Surya, S., \& Kishore, G. (2012). Cassia fistula Linn. :pharmacognostic, phytochemical and pharmacological review. Critical Review in Pharmaceutical Sciences, 1, 43-65.

Ward, M. J. (2005). Patterns of box mistletoe Amyema miquelii infection and pink gum Eucalyptus fasciculosa condition in the Mount Lofty Ranges, South Australia. Forest Ecology and Management, 213(1), 1-14. doi.org/10.1016/j.fore co.2005.03.011

Xiao, L. Y., \& Pu, Z. H. (1988). An investigation on the harm of the Loranthaceae in Xishuangbanna, Yunnan. Acta Botanica Yunnanica, 10, 69-78. 